\title{
Drug Used at Visit
}

National Cancer Institute

\section{Source}

National Cancer Institute. Drug Used at Visit. NCI Thesaurus. Code C157391.

An indication that a specified drug was used during a visit. 